\author{
St ud i P hilos o p hic a \\ Wratis l a vi e n s i a \\ vol. XIV, fasc. 2 (2019) \\ DOI: $10.19195 / 1895-8001.14 .2 .7$
}

MATEUSZ PALKA

ORCID: 0000-0002-9876-9955

Uniwersytet Wrocławski

\title{
Rozbity na tysiące kawałków Paryż Waltera Benjamina
}

Po rodzinnym Berlinie Paryż był jednym z tych miast, z którym Walter Benjamin czuł się najbardziej związany. Oba stawały się przedmiotem jego refleksji poświęconych architekturze, historii, surrealizmowi, językowi czy snom, jak również własnemu życiu i wspomnieniom. To właśnie miasta wraz z ich mikrokosmosem, zgęszczeniem, wielowymiarowością oraz indywidualnym, wywierającym silny wpływ na ludzkie doświadczenie charakterem fascynowały go znacznie bardziej niż szersze środowiska, które — jak nierzadko się później okazywało — stawały mu się ideologicznie i politycznie wrogie i w obrębie których nie był w stanie obronić prawa do własnego bezpieczeństwa.

Benjamin odwiedził Paryż po raz pierwszy w 1913 roku. Nazywał go ,stolicą XIX stulecia" - a więc najważniejszym centrum nie w geograficznym sensie, lecz wyjątkowym momentem na temporalnej mapie Europy. Uwiedziony początkowo przez europejskość i otwartość francuskiej metropolii rozczarował się w kolejnych latach niedostatecznie ciepłym przyjęciem go przez paryski świat. Nieustannie inspirowała go jednak francuska literatura i sztuka — głównie surrealizm i twórczość Louisa Aragona, a także kręgi Georgesa Bataile'a.

W rok po pierwszej wizycie w Paryżu rozpoczął przekład wierszy Charlesa Baudelaire'a, a podczas pobytu w tym mieście w 1926 roku wraz z Franzem Hesslem tłumaczył $W$ poszukiwaniu straconego czasu Marcela Prousta (tomy: $W$ cieniu zakwitających dziewcząt oraz Strona Guermantes). Rok później zaczął pracę nad największym i nigdy nieukończonym dziełem, Paryskimi pasażami, które przygotowywał w Bibliotece Narodowej Francji. Pisał tę książkę z przerwami aż do ucieczki z Paryża w czerwcu 1940 roku. W tym czasie, w liście do swego wieloletniego przyjaciela Hugona von Hofmannsthala, wspominał o planach porównania dramatu niemieckiego i francuskiego w osobnej pracy badawczej, mającej nawiązy- 
wać do jego przyszłej książki Źródło dramatu żałobnego w Niemczech. Jego słynny esej Dzieło sztuki w epoce mechanicznej reprodukcji został po raz pierwszy wydany w przekładzie Pierre'a Klossowskiego na język francuski w 1936 roku w czasopiśmie Instytutu Badań Społecznych.

Po opuszczeniu Niemiec w marcu 1933 roku, pragnąc pozostać w Paryżu, bezskutecznie szukał pomocy finansowej w Duńskim Komitecie Wspierania Intelektualistów. Środki, jakimi dysponował, dorabiając skromnymi honorariami, nie pozwalały mu jednak na utrzymanie się w drogiej metropolii. W 1935 roku pomogło mu mieszkające w Danii małżeństwo - Helene Weigl i Bertolt Brecht. Dla Benjamina nastąpił czas licznych przeprowadzek: Paryż, Ibiza, ponownie Paryż (gdzie trzykrotnie zmieniał hotele), Dania, Nicea, Monaco, San Remo i po raz kolejny Paryż. Kontynuował pisanie prac o Baudelairze, we Francji zacieśnił przyjaźń z Hannah Arendt.

Po wybuchu wojny powierzył swoje rękopisy Georgesowi Bataille’owi, któremu udało się ukryć je w Bibliotece Narodowej w Paryżu, i opuścił miasto. W styczniu 1940 roku na parę miesięcy wrócił do Paryża, gdzie napisał Tezy historiozoficzne, a następnie 13 czerwca, dzień przed wkroczeniem Niemców do stolicy, uciekł do Lourdes wraz ze swoją siostrą Dorą. Gestapo splądrowało jego paryskie mieszkanie. Zaplanowana ucieczka do Hiszpanii przez Pireneje, którą zorganizowała działaczka francuskiego ruchu oporu Lisa Fittko, nie udała się w wyniku zamknięcia granicy i anulowania wiz.

Sytuacja wydawała się Benjaminowi bez wyjścia. Przed podaniem sobie śmiertelnej dawki morfiny, 25 września napisał krótki pożegnalny list do jednej z uciekinierek Henny Gurland, przyszłej żony Ericha Fromma. Prosił, aby wytłumaczyła jego przyjacielowi Adorno podjętą przez siebie decyzję odebrania sobie życia. List napisał po francusku.

Przedruk artykułu Paris, die Stadt im Spiegel. Liebeserklärungen der Dichter und Künstler an die „Hauptstadt der Welt” Waltera Benjamina został po raz pierwszy opublikowany anonimowo w styczniowym numerze „Vogue'a” z 1929 roku. Oryginał zaginął. Niektóre podjęte w nim refleksje wykorzystane zostały później w nieukończonej rozprawie Pasaże w rozdziale „R" - Lustra.

Źródło: W. Benjamin, Gesammelte Schriften. Unter Mitwirkung von Theodor W. Adorno und Gershom Scholem, R. Tiedemann i H. Schweppenhäuser (hrsg.), Bd. IV, Frankfurt am Main 1972, s. 356-359. 